\title{
Influence of Chaining Pinyon-Juniper on Net Radiation, Solar Radiation, and Wind
}

\section{GERALD F. GIFFORD}

Highlight: Net and solar radiation, and wind were measured during parts of 1968 and 1969 on a pinyon-juniper site in southwestern Utah. Treatments were chaining-with-debris windrowed, chaining-with-debris-in-place, and undisturbed woodland. Net radiation on the chain-windrow treatment and chain-debris treatment averaged 71 and $91 \%$, respectively, of that measured on undisturbed woodland. Albedo values averaged 13 and $12 \%$ for the 2 years on woodland plots, 21 and $19 \%$ on the chain-windrow treatment, and 13 and $14 \%$ on the chain-debris treatment. Roughly 3 miles of wind las measured at approximately mid-canopy height) occurred on the chained treatments for every 1 mile measured in the woodland.

The pinyon-juniper (Pinus sp.Juniperus sp.) type extends over approximately 60 million acres in the western United States (Dortignac, 1960). The trees have been removed over several hundred thousand acres by chaining, burning, bulldozing, or spraying. Grass was artifically seeded on some sites, but native species (shrubs and grasses) were allowed to naturally seed other sites.

The study was designed to provide some preliminary data on microclimatic changes that occur when trees are removed from pinyon-juniper sites about 40 miles southwest of Milford in southwestern Utah.

\section{Methods and Site Description}

The study site was chained (using a large anchor chain between two tractors) in the fall of 1967. The three chaining treatments were chaining with all debris windrowed (crested wheatgrass [Agropyron cristatum] drilled at $8 \mathrm{lbs}$ /acre); double chaining with debris-in-place (crested wheatgrass broadcast seeded at $8 \mathrm{lbs}$./acre); and no chaining. Approximately 30 to 40 acres were involved in each treatment. All treatments were fenced to exclude livestock.

The woodland plots (control) had a 20 to $45 \%$ canopy coverage of pinyon and juniper trees. Shrub cover consisted of big sagebrush (Artemisia tridentata), black sagebrush (Artemisia nova), and small rabbitbrush (Chrysothamnus sp.). Scattered plants of Eriogonum sp., Aster sp., and Salsola kali were also present. Vegetation on the chain-with-windrowing treatment was limited during the duration of this study; crested wheatgrass seedlings were the dominant species

The author is associate professor, Range Watershed Science, Watershed Science Unit, Utah State University at Logan.

This study was conducted in cooperation with the Bureau of Land Management under contract 14-11-008-2837, (Journal Paper 1241, Utah Agricultural Experiment Station, Utah State Univ. Logan.)

Manuscript received January 31, 1972 . present. Seedling canopy coverage was less than $20 \%$ during 1968 and from 10 to $20 \%$ during 1969 . On the chain-with debris-in-place plot, the crested wheatgrass seedling canopy coverage was less than $10 \%$ during both 1968 and 1969 ; shrub canopy coverage (all species) was $15 \%$ or less during both years.

Soils are sandy loam in texture and were derived from basaltic parent materials.

During the summer of 1968 climatic stations were established in each of the three treatments. Net radiation was measured at $20 \mathrm{ft}$ above the ground surface in the undisturbed and chained-with-debris-in-place treatments and at $8 \mathrm{ft}$ above the ground surface in the chained-with-windrowing treatment. The difference in measurement heights was a reflection of the amount of spatial variability necessary for viewing by each radiometer to insure a single measure as representative as possible. For radiometers mounted $20 \mathrm{ft}$ above the soil surface, nine-tenths of the field of view is within a diameter of $115 \mathrm{ft}$ (Reifsnyder and Lull, 1965). A Fritschen (1963) type miniature net radiometer, as modified by Campbell et al. (1964), was used to make net radiation mcasurcments. Measurements were recorded on a Rustrak Model $8812 \mathrm{v} \mathrm{dc}$ MA recorder with an unregulated motor. The radiometers (and all other instruments) were not moved about but remained at or very near the same position for the duration of the study (Fig. 1). The net radiation measured is the difference between the downward flux, consisting of direct and diffuse solar radiation and atmospheric thermal radiation, and the upward flux, consisting of reflected solar and thermal radiation and emitted thermal radiation.

Incoming and reflected solar radiation was measured with a Sol-A-Meter (silicon cell) from the Yellot Solar Energy Laboratory. Dirmhirm (1968) has discussed the use of this instrument in radiation studies. A single Sol-A-Meter measured incoming solar radiation in the open at a height of approximately $6 \mathrm{ft}$. All measures of reflected shortwave radiation were made at the same height above the soil surface as the net radiation measures. Measurements were recorded on a Rustrak Model $8812 \mathrm{v}$ dc MV recorder with an unregulated motor.

Wind was measured at a height of 11 feet (roughly mid-canopy height) with Belford Model 9924A totalizing anemometers.

\section{Results and Discussion}

\section{Net Radiation}

Net radiation values for each chaining treatment are shown in Figure 2 for the period August 24 to September 22, 1968. Data for the woodland were available only for the period September 7 to September 22, 1968. 


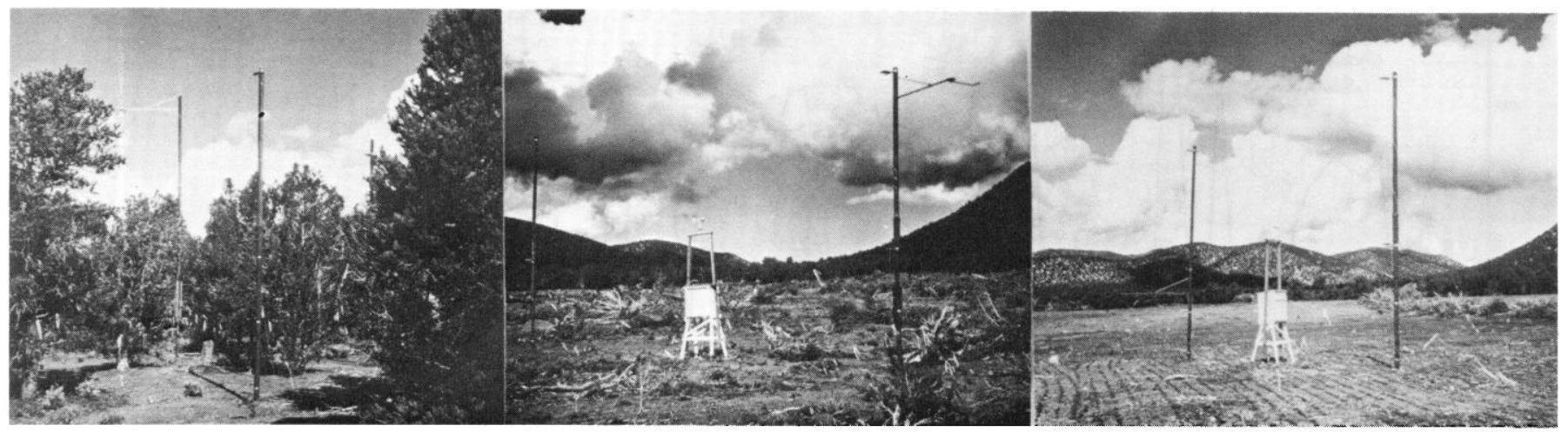

Fig. 1. Instrumentation of plots used in the study: (left) control plot, (middle) chain-with-debris-in-place treatment and (right) chain-withwindrow treatment.

Highest net radiation values were measured over the control treatment, followed by the chain-with-debris-in-place treatment. The chain-with-windrow treatment gave the lowest net radiation values. Net radiation in the chain-with-windrow treatment averaged $71 \%$ (range was 48 to $85 \%$ ) of that measured on the woodland plot. Net radiation on the chain-with-debris-inplace treatment averaged $91 \%$ (range was 80 to 105\%) of that measured on the woodland plot.

The above results are somewhat expected. The net radiation $\left(R_{n}\right)$ of a surface is the algebraic sum of the downward flux of solar radiation $\left(\mathrm{R}_{\mathrm{sd}}\right)$ from sun and sky, the downward infrared or thermal radiation flux $\left(\mathrm{R}_{\mathrm{id}}\right)$ from the atmosphere, and the upward flux of reflected solar radiation $\left(R_{s u}\right)$, and the upward infrared radiation flux $\left(R_{i u}\right)$ from the surface. Thus:

$$
\mathrm{R}_{\mathrm{n}}=\mathrm{R}_{\mathrm{sd}}+\mathrm{R}_{\mathrm{id}}-\mathrm{R}_{\mathrm{su}}-\mathrm{R}_{\mathrm{iu}} \text {. }
$$

The downward fluxes $R_{s d}$ and $R_{i d}$ are controlled by atmospheric conditions and are usually rather constant except under partly cloudy skies. The magnitude of $\mathrm{R}_{\mathrm{su}}$ is dependent on the reflective properties of the surface, the ratio of outgoing (reflected) solar radiation to incoming being referred to as the albedo (a). Thus:

$$
\mathrm{R}_{\mathrm{su}}=\mathrm{aR}_{\mathrm{sd}} \text {. }
$$

The flux of $R_{i u}$ is dependent primarily on radiation emitted by the surface, but the reflected part of the downward infra-

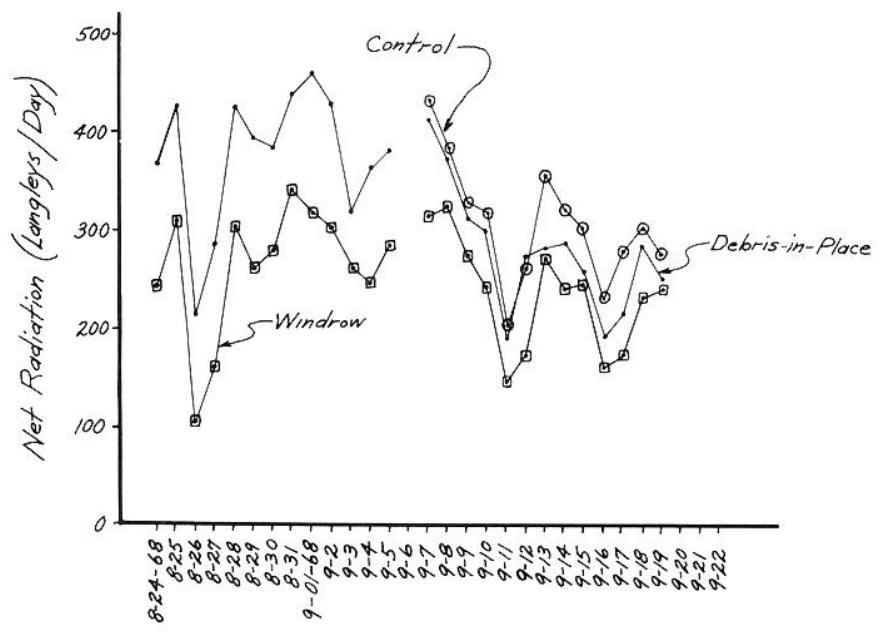

Fig. 2. Net radiation as measured on various dates over each treatment. red radiation is also included. Using the absorptivity or emissivity $\epsilon$, the Stefan-Boltzmann constant $\sigma$ and the fact that surface temperature $\left(T_{0}\right)$ governs radiation emitted by the surface, then

$$
\mathrm{R}_{\mathrm{iu}}=\epsilon \sigma \mathrm{T}_{\mathrm{o}}{ }^{4}+(1-\epsilon) \mathrm{R}_{\mathrm{id}} \text {. }
$$

If we can assume that $\epsilon=1$ (usual range 0.95 to 0.98 for natural surfaces), then combining and rearranging (1), (2), and (3) gives

$$
\mathrm{R}_{\mathrm{n}}=(1-\mathrm{a}) \mathrm{R}_{\mathrm{sd}}+\mathrm{R}_{\mathrm{id}}-\sigma \mathrm{T}_{\mathrm{o}}{ }^{4} .
$$

Examination of (4) will show that net radiation is dependent on the albedo and surface temperature if downward components $\left(R_{s d}, R_{i d}\right)$ are somewhat constant. These conditions were closely approximated in this study. It will be seen later that albedo of the chain-with-windrow treatment was considerably higher than that measured on the other two treatments. Presence of debris scattered about on the debris-inplace treatment would tend to reduce albedo, as would the presence of standing trees.

Influence of surface temperature differences on net radiation in this study is not known at this time, but Federer (1968) has found in the Northeastern states that variations in surface temperature and albedo were about equally important in affecting net radiation. Baumgartner (1965) and Tromble and Simanton (1969) have found that net radiation values over open areas may be only about $60 \%$ of that measured over a forest canopy. Tajchman (1971) found that total net radiation over a spruce forest in Germany was $20 \%$ greater than that over alfalfa and $16 \%$ greater than that over potatoes.

\section{Solar Radiation}

An example of values for incoming and reflected shortwave for two periods is shown in Figure 3. Data were also available for the periods August 10 to September 5 and October 1 to October 31, 1968. During the 1968 measurement period, the albedo (ratio of reflected to incoming shortwave) of the chain-with-windrow treatment averaged $21 \%$ (range of 16 to $26 \%$ ), or not quite twice the albedo of the chain-with-debrisin-place treatment (average 13\%, range 7 to $20 \%$ ) and the woodland (average 13\%, range 9 to $21 \%$ ).

The above relationship held for the 1969 measurements also. Albedo of the chain-with-windrow treatment averaged $19 \%$ (range of 12 to $25 \%$ ), as compared with $14 \%$ for the chain-with-debris-in-place treatment (range of 9 to 23\%) and $12 \%$ for the control treatment (range of 4 to $22 \%$ ). Some slight changes are to be expected, as vegetation increased 


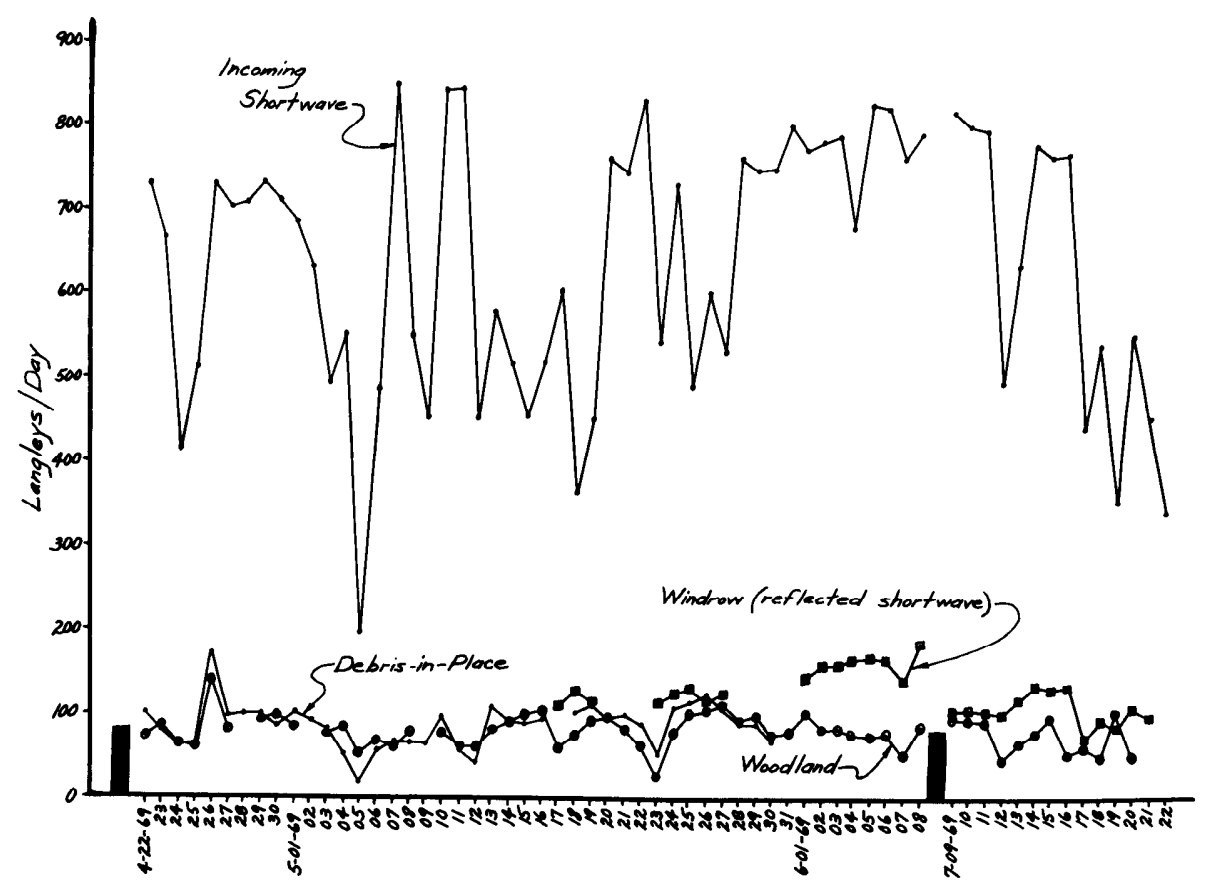

Fig. 3. Incoming and reflected solar radiation for two select periods.

somewhat on both chaining treatments.

Figure 4 gives some idea of the magnitude of change in reflected solar radiation which may be expected following a snow storm. No data are available for incoming solar radiation. The increased reflectivity in response to snow is greatest in the chain-with-window treatment, intermediate in the chain-withdebris-in-place treatment, and least in the control treatment.

Results of both net radiation and albedo measurements agree closely with those of Hornbeck (1970), who compared the radiant energy of clearcut and forested sites in West Virginia.

\section{Wind}

Average miles of wind per day at mid-canopy height on each treatment as averaged over approximately 2 -week periods were analyzed for July 14 to November 30, 1968 and for April 4 to July 11, 1969. Relationships were similar for both 1968 and 1969. In general, for each mile of wind recorded in woodland plots at mid-canopy height, approximately 3 miles was recorded on each of the two chaining treatments. Slightly more wind was recorded during all time intervals on the chain-with-windrow treatment than on the chain-with-debrisin-place treatment.

\section{Summary}

The objective of this study was to provide some preliminary information regarding microclimatic changes that may occur when a pinyon-juniper site is significantly altered by removal of trees. This paper has provided some insight regarding net radiation differences, albedo differences, and wind relationships.

Net radiation measurements were greatest over the natural pinyon-juniper woodland. Net radiation on the chain-withwindrow treatment and chain-with-debris-in-place treatment averaged 71 and $91 \%$, respectively, of that measured on the woodland plot. Part of the difference is due to a higher albedo on the chain-with-windrow treatment.

Average albedo values varied only slightly during measure- ment periods in 1968 and 1969. Albedo values averaged 13 and $12 \%$, respectively, for the 2 years on woodland plots, 21 and $19 \%$ on the chain-with-windrow treatment, and 13 and $14 \%$ on the chain-with-debris-in-place treatment. Presence of debris on the ground in the debris-in-place treatment tended to bring albedo values close to those measured on woodland plots, at least during snow-free periods. Following a snow storm, the amount of reflected solar radiation increased most of the chain-with-windrow treatment and least on the woodland treatment.

As might be expected, wind (as measured at approximately mid-canopy height) was greatest where standing trees were absent. Roughly 3 miles of wind occurred on chained treatments for every 1 mile measured in the woodland.

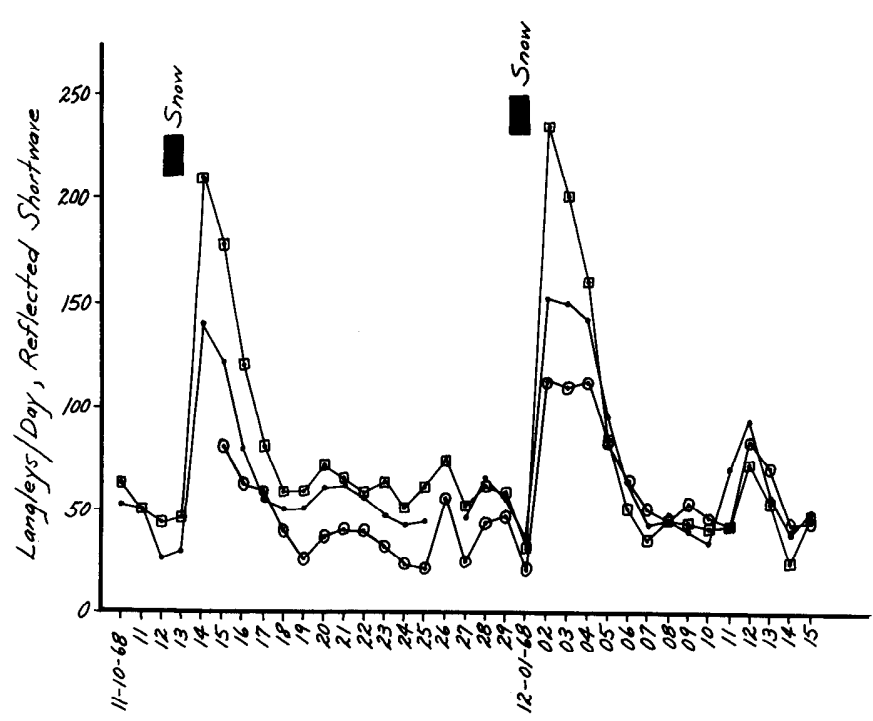

Fig. 4. Reflected solar radiation on the three treatments following two periods of snow. Squares represent the chain-with-windrow treatment, circles the natural woodland, and dots the chain-withdebris-in-place treatment. 


\section{Literature Cited}

Baumgartner, A. 1965. Energetic bases for differential vaporization from desert and agricultural lands. In Intern. Symp. on Forest Hydrology, Pergamon Press, Oxford.

Campbell, G. W., G. L. Ashcroft, and S. A. Taylor. 1964. Thermistor sensor for the miniature net radiometer. J. Applied Meteorol. $3: 640-642$.

Dirmhirm, 1. 1968. On the use of silicon cells in meteorological radiation studies. J. Applied Meteorol. 7:702-807.

Dortignac, E. J. 1960. Water yield from pinyon-juniper woodland. In Symp. on water yield in relation to environment in the southwestern United States, Sul Ross State College, Alpine, Texas:
$16-27$.

Federer, C. A. 1968. Spatial variation of net radiation, albedo, and surface tempcrature of forest. J. Applied Meteorol. 7:789-795.

Fritschen, L. J. 1963. Construction and evaluation of a miniature net radiometer. J. Applied Meteorol. 2:165-172.

Hornbeck, J. W. 1970. The radiant encrgy budget of clearcut and forested sites in West Virginia. Forest Sci. 16:139-145.

Reifsnyder, W. E., and H. W. Lull. 1965. Radiant energy in relation to forests. U. S. Dep. Agr. Tech. Bull. 1344: $111 \mathrm{p}$.

Tajchmann, S. J. 1971. Evapotranspiration and energy balances of forest and field. Water Resour. Res. 7:511-523.

Tromble, J. M., and J. R. Simanton. 1969. Net radiation in a riparian mesquite community. Water Resour. Res. 5:1139-1141. 